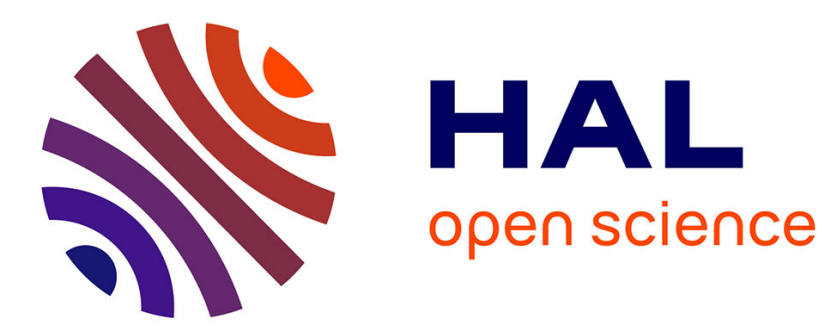

\title{
Epitaxial waveguide laser of aluminium garnet
}

\author{
B. Ferrand, B. Chambaz, Isabelle Chartier, B. François, D. Pelenc, C. Wyon
}

\section{To cite this version:}

B. Ferrand, B. Chambaz, Isabelle Chartier, B. François, D. Pelenc, et al.. Epitaxial waveguide laser of aluminium garnet. Journal de Physique IV Proceedings, 1994, 04 (C4), pp.C4-591-C4-591. 10.1051/jp4:19944142 . jpa-00252597

\section{HAL Id: jpa-00252597 https://hal.science/jpa-00252597}

Submitted on 1 Jan 1994

HAL is a multi-disciplinary open access archive for the deposit and dissemination of scientific research documents, whether they are published or not. The documents may come from teaching and research institutions in France or abroad, or from public or private research centers.
L'archive ouverte pluridisciplinaire HAL, est destinée au dépôt et à la diffusion de documents scientifiques de niveau recherche, publiés ou non, émanant des établissements d'enseignement et de recherche français ou étrangers, des laboratoires publics ou privés. 


\title{
Epitaxial waveguide laser of aluminium garnet
}

\author{
B. FERRAND, B. CHAMBAZ, I. CHARTIER, B. FRANÇOIS, D. PELENC and C. WYON
}

LETI, CEA-Technologies Avancées, DOPT-CENG, 85X, 38041 Grenoble cedex, France

Since few years in the LETI, we studied the growth by Liquid Phase Epitaxy of YAG single crystal layers [1]. In collaboration with the University of Southampton, we investigated the properties of such layers for waveguide laser applications [2,3,4]. The advantages of LPE technique are the easy control of the layer thickness between 1 and $100 \mu \mathrm{m}$, the large choice of dopants and concentrations (Nd, $\mathrm{Yb}, \mathrm{Er}, \mathrm{Tm}, \mathrm{Ho} . .$. in $\mathrm{YAG}$ ) and the possibility to obtain a higher doping level than in bulk crystals (Nd in YAG for example). In order to realize a waveguide, the refractive index can be adjusted by substitution of others cations like Ga. The properties of the waveguide are optimized by the growth, again by LPE, of an undoped YAG cladding layer.

The main interests of such a waveguide in laser applications are a better matching of the pump and emitted beams, a possible transversal guiding of the pump beam, a low threshold, and the possibility of a selection of the fundamental mode by the thickness control. A diode pumped epitaxial waveguide laser seems to be interesting for eye-safe, high power or upconversion laser applications.

In this paper, we present laser performances of doped YAG waveguides in respect with the growth procedure and the waveguides preparation. The good quality of the waveguides (losses $<0.1 \mathrm{~dB} / \mathrm{cm}$ ) and the significant laser results obtained, namely for ytterbium doped YAG (low threshold: $40 \mathrm{~mW}$ absorbed and large slope efficiency: $80 \%$ ), confirm the potential interest of such devices.

[1] B. Ferrand, D. Pelenc, I. Chartier, C. Wyon, Journal of Crystal Growth 128, 966 (1993).

[2] I. Chartier, B. Ferrand, D. Pelenc, S.J. Field, D.C. Hanna, A.C. Large, D.P. Shepherd, A.C. Tropper, Optics Letters, Vol 17, 229, (1992).

[3] D.C. Hanna, A.C. Large, D.P. Shepherd, A.C. Tropper, I. Chartier, B. Ferrand, D. Pelenc, OSA Topical Meeting ASSL, New Orleans, paper JWD-4, Feb 1993.

[4] D. Pelenc, B. Chambaz, I. Chartier, B. Ferrand, D.C. Hanna, A.C. Large, D.P. Shepherd, A.C. Tropper, ECIO 93 Conference, Neuchatel, paper 3-8, April 1993. 